Central Newfoundland and the Source of the Gander River

Author(s): J. G. Millais

Source: The Geographical Journal, Vol. 27, No. 4 (Apr., 1906), pp. 382-392

Published by: geographicalj

Stable URL: http://www.jstor.org/stable/1776238

Accessed: 25-06-2016 12:46 UTC

Your use of the JSTOR archive indicates your acceptance of the Terms \& Conditions of Use, available at

http://about.jstor.org/terms

JSTOR is a not-for-profit service that helps scholars, researchers, and students discover, use, and build upon a wide range of content in a trusted digital archive. We use information technology and tools to increase productivity and facilitate new forms of scholarship. For more information about JSTOR, please contact support@jstor.org.

The Royal Geographical Society (with the Institute of British Geographers), Wiley are collaborating with JSTOR to digitize, preserve and extend access to The Geographical Journal 
Tarawera is especially interesting. During the eruption the bed of Tarawera creek, which drains the lake of the same name, filled up, and the lake immediately started to rise. For years some of the water found exit through cracks in the tufa which filled the creek bed, appearing at the base of the Tatauahape escarpment, some 2 or 3 miles below the lake. Just after the eruption the lake is said to have risen 28 feet; from that time until November, 1904, it ascended 42 feet in all. Then the water rose over the dam of tufa which prevented its exit along the old channel, breaking much of it away. The water in the lake almost immediately dropped over 11 feet, and, flowing along its old channel, fell over the Tatauahape escarpment, forming the falls of the same name. Low cliffs, marking the former level of the lake, testify to the changes which its surface has undergone.

The Taupo volcanic zone, with its abundant evidence of expiring vulcanism in the form of geysers, fumaroles, and boiling springs, forms one of the most fascinating areas for scientific investigation, in a country so rich in natural phenomena as the islands of New Zealand.

\section{CENTRAL NEWFOUNDLAND AND THE SOURCE OF THE GANDER RIVER.}

By J. G. MILLAIS, F.Z.S.

IT is somewhat surprising that the interior of Newfoundland should be less known than parts of Central Africa or the Arctic Regions, and still more so when we consider that the island has been occupied by Englishmen since the days of Henry VII., and is our oldest colonial possession. But the reason for this lack of enterprise is not far to seek. A colony must, in the first place, be in possession of funds to send out properly equipped geographical expeditions to ascertain its natural features, and in this respect Newfoundland has been somewhat handicapped, but not to such an extent that there is any excuse for the lack of ambition to know their own country on the part of the various Newfoundland governments. Parsimony and the conditions of trade have ever been the island's watchword, so practically nothing was done to ascertain a knowledge of the interior or its natural resources until William Cormack made his memorable journey in 1822 . In spite of considerable opposition, this brave pioneer set forth on foot, accompanied by one Indian, Sylvester by name, and crossed the island from Trinity bay to St. George's bay, taking just over two months in which to complete the arduous journey. The introduction to the short account of his travels * is both instructive and sarcastic, showing as it does the attitude of the authorities towards his undertaking.

* 'Narrative of a Journey across the Island of Newfoundland.' By W. E. Cormack. 'The only one ever performed by a European. St. John's : 1873. 


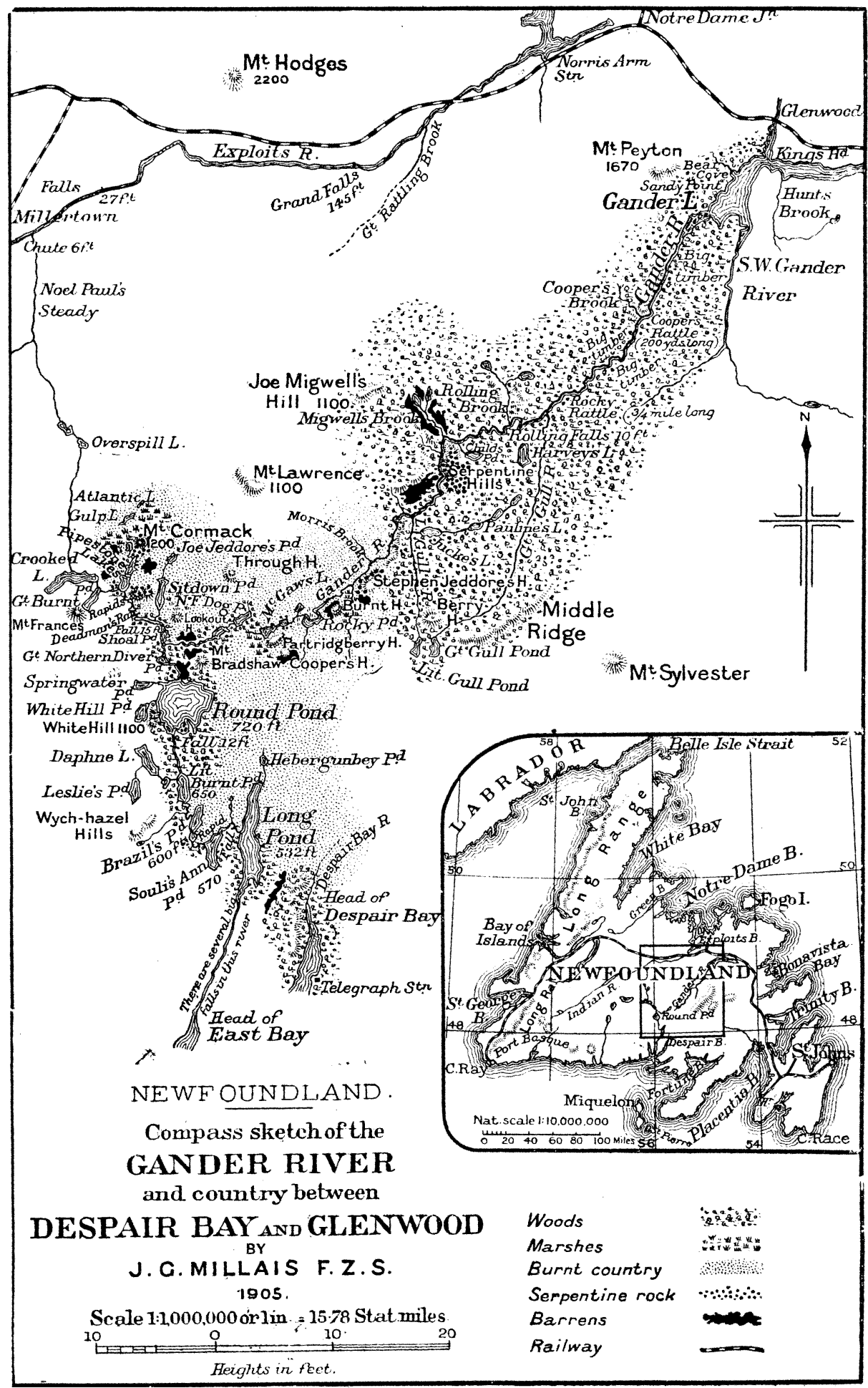


" Early in the spring of 1822, being in Newfoundland, a far-famed country in which I felt a most lively interest, and free from professional engagement, I determined upon exploring the interior of the island, a region almost totally unknown, and concerning which and its inhabitants, the Red Indians, who were supposed to occupy the whole of it, the most besotted conjectures were entertained, particularly by the chief delegated public authorities, to which quarter one was inclined to look for some proofs of a feeling of interest for the condition of the country, through the means of which they obtained their bread."

Cormack, although not a geographer, marked several important points, such as Mount Sylvester, which he named after his faithful Indian, the two Maelpegs, and George IV. lake, whilst Cormack lake and Mount Cormack, the central spot of the interior, were named after him. About the year 1868 Alexander Murray and William Howley were granted small funds to survey the interior. Sometimes they were not even allowed to choose their followers, a most important point in every expedition. Yet the amount of work done by these able geographers will bear lasting tribute to their energy and determination. The main waterways leading into the interior, such as Grand lake, Red Indian lake, the Terra Nova, Long Harbour river, the East bay, and the La Poile river were all surveyed and charted, principally by Mr. Howley, whose great work has never received proper recognition, although he has spent his best years on the subject, and risked his life many times. The difficulties of travel in Newfoundland are such that none but the most experienced royagers can surmount them, and Mr. Howley has always been accompanied by Indians, except on occasions when the various Governments have forced their useless partisans in his service.

Naturally it was quite impossible for even such a man as Howley to be invariably successful in his work, and much of it had been done from hearsay or conjecture and by adhering closely to the waterways themselves. Consequently matters of importance, such as the natural features in shape of mountains aud lakes in the immediate neighbourhood of the waterways, were often incorrectly charted or left out altogether. On the whole, however, Mr. Howley's work is most reliable.

It was to fill up some of the gaps in the unwritten page, and to discover, if possible, the actual source of the Gander, the second largest river in Newfoundland, that $I$ set out on my third expedition to the country in 1905. After a month spent in whale hunting, and in examining whales for a work on British mammals on which $I$ am engaged, I was met at Placentia on September 1 by my friend John McGaw. McGaw had previously studied geography and surveying, and had received considerable help in map-making from the Geographical Society, who seem always ready to assist their pupils, an unselfish 
duty which other scientific bodies might follow with advantage. I found him an admirable companion, a good shot, and an industrious worker at whatever subject he turned his hand. It made our duties light and pleasant, for whilst he surveyed one line of country I could attend to another, and in the evening we joined forces and made our map together.

Dense fog enclosed the whole of the south coast; but when we arrived, after two days in a steamer and one in a schooner, at our starting-place on the banks of a small river at the head of Despair bay, the sun shone out brilliantly, and for a month and more we enjoyed the most delightful weather, the average temperature being very much the same as Scotland, although somewhat colder at night. Starting on September 3, and accompanied by six packers, exclusive of our own four helpers, we journeyed across a small range of hills to the large lake known as Long pond, a distance of 6 miles from the head of Iespair bay. Here the packers left us to our own devices, and we travelled across Long pond 2 miles, and up the East Bay river to Soul's Ann pond, another large lake, where, bad weather coming on, we were detained for a day and a half.

To the east of Souli's Ann pond the whole country is sparsely wooded, except round the lakes and rivers, where the timber is more dense. The trees consist of white pine, red spruce, black spruce, larch, white and black birch, poplars (haps), maple, mountain ash (dogwood), choke cherry, small wild cherry, hazel, and alder.

The "open ground" or "country" is covered with "Indian tea" bush, goudie (Kalmia glauca), a lovely flowering shrub, and dwarf spruce, creeping birch, and juniper. On the ground are various mosses, notably the common reindeer moss, and a large number of berries, cloudberry, cranberry, partridge-berry, bearberry (Empetum nigrum), a favourite food of the Canada goose, whilst blueberries grow in vast quantities wherever the forest has been recently burnt.

Immediately round Souli's Ann pond the whole country is " burnt," and the melancholy area of destruction extends as far as the eye can reach to the east and west. This great gaunt sea of grey poles is now interspersed with young and growing timber of various kinds, some of it 10 and 15 feet high, and affords good cover for game, and in the course of twenty years the country will again recover itself to a certain extent. It takes about eighty years for a forest to grow.

The fire which created this terrible destruction began in the autumn of 1893, immediately to the west of Brazil's pond. Its origin is unknown, but in a dry season it made rapid headway and burnt out the whole of Souli's Ann, Brazil, Little Burnt, and the eastern side of Round pond. The Indians say that it smouldered all the winter and then started again in the spring, and, favoured by a south-west wind, burnt as far north as it could go to Crooked lake and Pipestone. It 
also worked down the Gander a short distance, and afterwards turned north-east along Great Rattling brook, and reached the railway at Badger brook, where it stopped. The western side of Round pond was missed by the fire, as well as a 5-mile strip of white pine near Great Rattling brook, a section reported to be the finest timber in Newfoundland. On September 7, in beantiful weather, we paddled up Brazil's pond, and at noon entered the short section of the East bay that connects this lake with Little Burnt pond, which is 650 feet above sea-level. ITere we found walking and frequent portages necessary, owing to the difficult and rocky character of the stream. It was in such places that our Indian guide, Joe Jeddore, exhibited his great skill as a canoeman. Standing up in the light 16 -foot basswood boat, he poled through rapids and past rocks where the less accomplished white men had to toil in the water emersed to their waists. The slippery character of the bed, too, created occasional disaster, and more than once we saw our faithful but somewhat clumsy followers disappear in the shallow torrent. But all discomfort was undergone by the Newfoundlanders with that cheerful stoicism which marks them as the hardy and good-natured race which they undoubtedly are.

At the north-west corner of Little Burnt pond, and looking from the ridge of the Wych-hazel hills, three lakes can be seen. One of these, Lake Daphne,* is about 3 miles long, and is a considerable sheet of water. In existing maps, Little Burnt pond seems to extend almost to the entrance of the large lake known as Round pond, but this we found to be a mistake, for there is a connecting portion of the East Bay river, nearly 3 miles in length, with a fall of 12 feet half a mile from Round pond.

In darkness we reached Round pond, the largest sheet of water in Central Newfoundland, and camped there for the night. Looking across the glassy waters away to the north-east, we could see the peak of Mount Bradshaw (called after one of Alex. Murray's able assistants) towering up above the green timber, and the only landmark visible. Round pond is another somewhat dangerous sheet of water to circumvent in small canoes, so we had to be careful next morning, as a good breeze was blowing astern as we headed northwards. At nine o'clock the Indian spied a large caribou stag about a mile ahead, and after a long and hard paddle I headed the beast and shot him at 150 yards. Meat being an essential compensation for hard work in the wilds, we were all delighted at this piece of good fortune, and continued our journey in high spirits to the north end of the lake, where a brook comes in from the north-west from a small pond called by the Indians Godoleick, or Spring-water pond. Here were noticed several good outcrops of pure petroleum oil, which made long green streaks on the shores of the lake.

* In Stanford's map, roughly marked as Ahwachanjeeth pond. 
Something might be made of these, as well as the abundant chrome-iron deposits which we afterwards saw near Mount Cormack, were transport not so difficult. At noon we continued westwards up steady water for $1 \frac{1}{2}$ mile, and then entered a small pond of about three-quarters of a mile long, which we called Great Northern Diver pond, from the abundance of these fine birds which are to be found there. Continuing upstream, we reached another unmarked pond of about a mile long, which might appropriately be named Shoal pond from its extreme shallowness.

This being a good point from which to strike east over the unknown country at the headquarters of the Gander, I decided to cache the

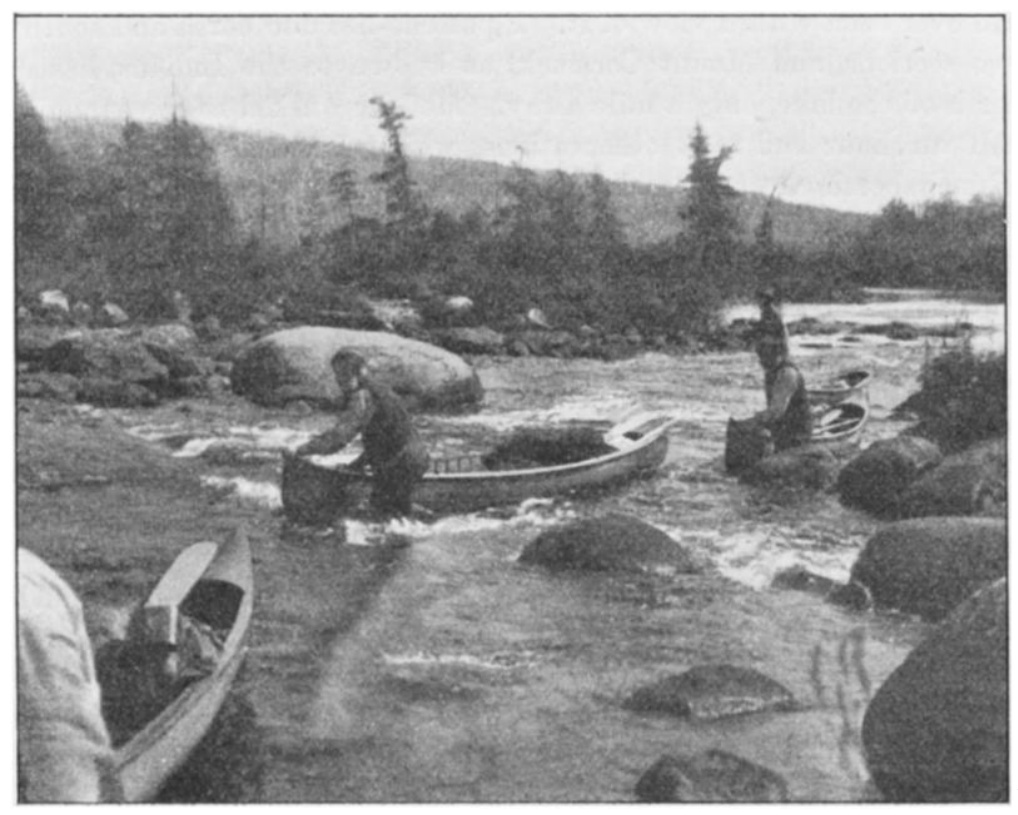

ASCENDING THE EAST BAY RIVER.

(Photo by J. McGaw, Esq.)

greater part of our stores on an island, where bears could not get at them, and to proceed northwards on the following day on a flying visit of a week's duration to Lakes Pipestone and Sit-down, Mount Cormack and its environs. Next day accordingly we travelled light with three canoes, and after spending a day in surveying the country to the east and marking the position of Look-out hill (850 feet), we continued up-stream for two days, reaching Pipestone on the evening of September 13. From Dead Man's rapids, a rough series of broken waters, the river was exceedingly difficult, and the men in constant trouble with the canoes, and at the rapids a portage of half a mile was found necessary.

Pipestone we found to be very unlike its aspect on the map. It lies 
almost due north and south, and is equally divided into two sections, each about $1 \frac{1}{2}$ mile long, and divided by a narrow bar of stones some 10 yards wide. The country was flat, burnt, and exceedingly melancholy, with its great sea of burnt poles. The two highest mountains within our view were Mount Cormack and Sit-down hill, which we ascertained to be 1200 and 1150 feet respectively. In several maps Mount Cormack is placed about 4 or more miles to the east of Pipestone, but such we found to be quite incorrect, there being no mountain of any size in this direction. The best map (Stanford's) places it 4 miles due east of Pipestone, which is itself marked in such a fictional manner as to cause one to wonder if the geographer who arranged its form and direction had ever been within view of it. Pipestone lies due north and south in two sections, and Mount Cormack, as known to the Indians, lies due north of the lake, only a mile away. McGaw walked to the summit in half an hour and took observations, whilst I visited Sit-down pond (Enuchabeesh Gospen) and Sit-down hill, from which a magnificent view was obtained. Seven miles to the west the trees above Great Burnt pond could be seen, and just south of this rose a high mountain apparently as lofty as Cormack, and which I called Mount Frances. We spent another day in the Pipestone country, making sketches of the country and seeing great numbers of female caribou, and a great rarity in the shape of a jet-black fox. To the north-east we noticed a brook flowing into Sit-down pond, and this comes from a small pond which we called Joe Jeddore's pond, as Joe was the only man who had ever been there.

When it rains in Newfoundland, the heavens seem to open and let loose the water, not in buckets, but in ponds, and a day of this saw us, like drowned rats, retreating to Shoal pond, where we had left our stores. The following morning we made a start up the brook which leads to Dog pond. The heavy rain of the previous day had been of great assistance to us, for we found that the small stream up which we had calculated to pack was negotiable by canoes if carefully handled. We made about 5 miles that day, and in the evening found ourselves on a small lake, which is named Little Dog pond, where we had the good fortune to pick up a couple of wild Indian boys named Matthews, who were hunting caribou. After some parley, they agreed to come with us for a week or ten days, and to help us over the difficult country between Dog pond and the Gander. The next day we made Dog pond, where I killed a caribou doe, as we were quite out of fresh meat, and paddled to the north-east corner of the lake, where we camped for the night.

This point is close to the watershed of the two great river systems of Newfoundland. We could not, therefore, rely on water to help us for any distance on our eastward journey, except by using for a short spell the three small lakes that were said to exist between Dog pond and Burnt hill, a mountain overlooking the Gander at a point where I 
hoped to again float the canoes. On the map this distance may be roughly estimated at 20 miles, but as the packers had to go the distance proved to be over 30 miles, whilst on foot and skirting the mountains to the south, McGaw and I found that we had walked nearly 40 miles.

After disposing of the stores and taking such things as would be necessary for myself and my companion for eight days, McGaw and I, with three Indians and Robert Saunders, set out on foot for the Gander river, intending to camp in a good hunting country that I had discovered in 1903. My plan was to shoot, if possible, two or three stags on the way and in the route of the oncoming packers, and thus supply them with fresh meat during their arduous undertaking. This we

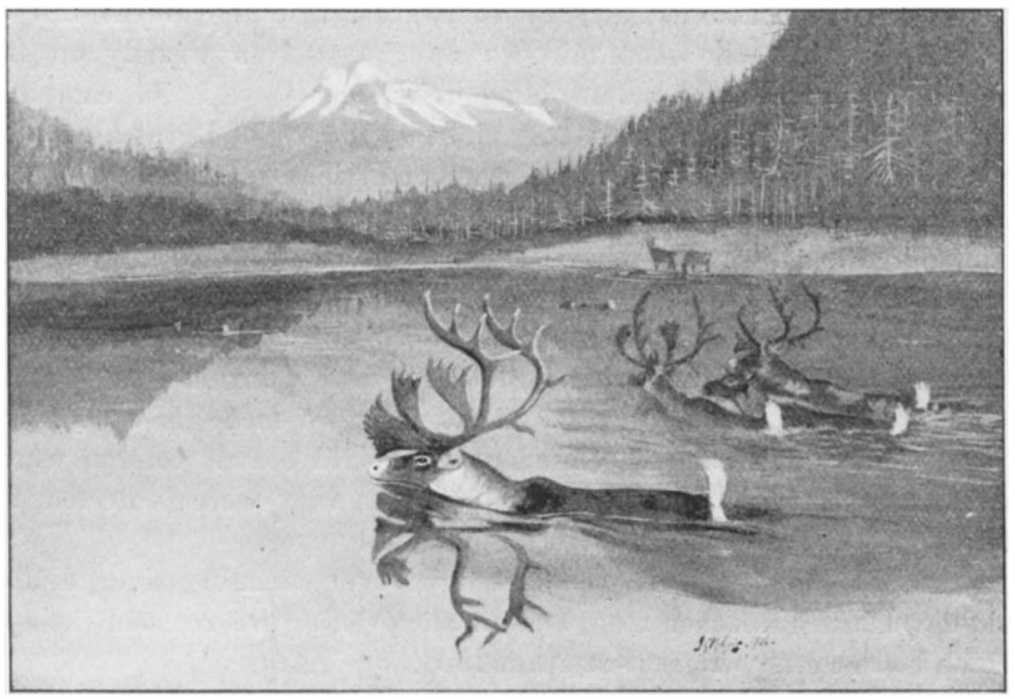

MOUNT CORMACK FROM PIPESTONE LAKE.

succeeded in doing at suitable intervals of distance, and accomplished the march in three days, going hard all the time.

Soon after leaving Dog pond on September 17, we found that which we had most earnestly desired, namely, a stream flowing eastwards into the first of the lakes, which I took the liberty of naming MoGaw's lake, after my industrious companion. By following this small brook back to its source, we can claim to have discovered the source of the Gander, the second largest river in Newfoundland, for the water system continues through the small lake chain to the eastward, and may be said to be a continuation of the main river, which had only been surveyed (by Howley) as far as Burnt hill. The actual source of the Gander comes from a small still pool surrounded by stunted spruces, and McGaw took an excellent photograph, which is here reproduced (see p. 391).

No. IV.-APRIL, 1906.] 
To the south of Lake McGaw we ascended to the summit of Partridgeberry hill, the highest mountain in Central Newfoundland, and obtained a magnificent view in all directions. The air was so rarefied that it was possible to make out Mount Peyton, or Blue hill, as it is called by the Indians, 70 miles away to the east. To the north Mount Lawrence and Joe Migwell's hill stood out by themselves. The great valley of the Gander lay at our feet, and we could trace its sinuous course for 20 miles from its source, through the lakes of McGaw and Rocky pond, to the widening "Steadies," beneath Burnt hill, 8 miles to the east, where it was lost in the green woods. All around us were rocky barrens and small marshes, across which countless caribou trails led away to the south, for this is a great migration route of the deer when they begin to travel. We continued all day eastwards, reaching Burnt hill at sunset. Beneath the mountain we flung ourselves wearily on the ground amongst the abundant blueberries, and thought of camping, when one of the Indians saw a stag right on the top of Burnt hill. Joe released from his pack was like a greyhound loosed from the slip, and the way he led me up that mountain after a 20-mile walk I shall not easily forget. However, I slew the stag, and we returned to the small woods, where we found McGaw had made a comfortable camp. The next day, September 18, we continued our journey over hard ground, and at midday McGaw killed his first stag, in a position that it could be easily utilized by our packers. That night we made the edge of the green timber, and camped close to a splendid beaver colony, whose occupants seemed to recognize the fact that they were protected, for they stared at their visitors with no unfriendly eyes.

The next day we journeyed down the ever-widening river, and at mid-day I killed another stag, and in the evening we reached the spot which had been my highest camp in 1903.

On the following day the Indians and Bob left us to our own devices, and returned to meet and help the packers, whilst McGaw and I hunted on the Gander for five days, and awaited the coming of the packers. During this period we killed three nice heads. On the night of the 24 th the men turned up with the outfit. They had met with no accidents, but had experienced an arduous journey for eight days since leaving Dog pond. The river itself had proved nothing but a series of shallows and rocky benches, in which it was unsafe to drag the canoes, so that the men had been forced to pack nearly the whole distance. The three stags had been of great comfort to them. They had devoured the whole of the edible parts, and this had given strength to do the work.

As my friend McGaw had only one more stag to kill under the terms of his licence, and was also anxious to catch an early steamer for home, he left me on September 25, and, travelling down the swollen Gander, reached Glenwood on October 2. 
I now set to work for eleven days to hunt seriously for big heads, and to explore the nature of the country westwards as far as Great Rattling brook, and southwards in the angle formed by the junction of the Little Gull river and the Gander on one side, and Great Gull river and the Middle ridge on the other, working as far east as Serpentine peak. This area is practically unknown, and in it $I$ found a small chain of four uncharted lakes, connected by a small stream, which joins the Little Gull about a mile from its debouchment into the Gander. Both the Little and Great Gull rivers start from two lakes situated within half a mile of one another under the western edge of the range known

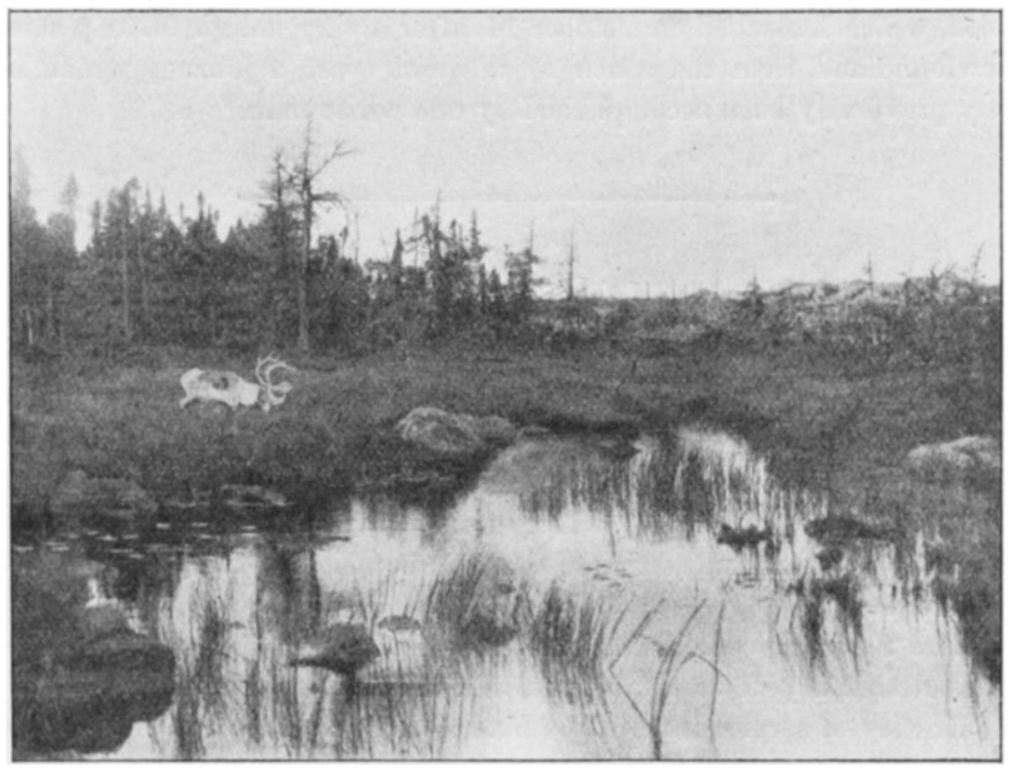

THE SOURCE OF THE GANDER.

(Photo by J. McGaw, Esq.)।

as the Middle ridge, the former flowing north and the latter north-east, where it joins the Gander about 3 miles below Rolling falls. In this angle formed by the starting-point of the two rivers rises a hill known to the Indians as Berry hill. The course of the Little Gull is short and swift, and after the first mile from the Gander it is exceedingly rocky, and would be difficult, but not impossible, to explore in canoes if there was plenty of water. The Great Gull pursues a more even course through a beautiful wooded valley, and on its lower reaches there are many "steadies."

The great outcrop of serpentine rocks known as Serpentine hills is a curious formation, and seems to give promise of mineral wealth, but so far the only two prospectors who have visited it have met with 
disappointment. Walking eastward from Serpentine peak one day, I found a good sheet of water named Harvey's lake, between Child's pond and the Great Gull. This connects with the Gander about a mile above the confluence of the Great Gull. I spent two days at Migwell's brook, so as to visit the ponds from which the stream is said to take its origin, and found that at a distance of 5 miles from the Gander, the brook branched and came from two small ponds half a mile apart. A similar origin takes place in the stream known to the Indians as Rolling brook, which enters the Gander at Rolling falls. From this point out to Glenwood the river and its environs are fully mapped, so that I need say no more. The weather breaking on October 10, I made for Glenwood, which I reached on October 14, after a very delightful trip across Newfoundland from the south to the east coast, a journey which has only previously been accomplished by one white man.*

\section{REPORT OF THE INDIAN SURVEY COMMITTEE, 1904-1905.}

Ir is no secret that the members of the Indian Survey Committee were not altogether in agreement as to the methods on which the proposed departmental reforms were to be carried out, but the general character and scope of those reforms seem to have offered no difficulty in principle, and they do not differ very widely from previous suggestions made to the Indian Government on more than one occasion within the last fifteen years or so.

The recurrent process of starving the Survey Department in order to meet treasury demands in times of financial pressure had resulted in inefficiency of service both in the field and in office. Whilst the demand for maps has been steadily increasing from year to year, the power to produce those maps had been decreasing both in men and money. Old mapping that was in need of revision was set aside or patched by the crude efforts of untrained employees, working under the local civil administration, with disastrous results; and the military mapping of the frontier, from the Indus to Persia, was confided to one working party with two military officers for its guidance.

The results of the committee's recommendations are mainly the strengthening of the department in all that appertains to the topographical or military mapping of India, and the separation of that branch of surveying from the cadastral or revenue surveys which are henceforth to be undertaken by local civil administrations, but will be under properly trained supervision from the central department. The

* A miner named Guzman left Despair Bay in 1873, under the guidance of Nicholas Jeddore, a Mićmac Indian, and reached Glenwood by this route. 